\title{
PROSES PERJODOHAN DAN KRITERIA KAFA'AH DALAM PERKAWINAN ANGGOTA LDII DESA MEDAENG KECAMATAN WARU KABUPATEN SIDOARJO
}

\author{
Sarifudin Zuhri \\ Yayasan Bahrul Hidayah Sukolegok Sukodono Sidoarjo. E-mail: \\ zuhry93gmail.com
}

\begin{abstract}
This paper is a bibliographical research on the process of marriage and kafa' ah criteria in LDII's members in Medaeng, Waru, Sidoarjo under the perspective of Islamic law. This study aims to answer the questions of how the matchmaking process in the marriage system of LDII's members in Medaeng, Waru, Sidoarjo and how the application of the concept of kafa'ah in LDII's members in Medaeng, Waru, Sidoarjo and how the maslahah analysis of the process of matchmaking and the concept of kafa' ab in LDII's members in Medaeng, Waru, Sidoarjo. This data of the research is obtained from the board of LDII of Medaeng, Waru, Sidoarjo which become the object of research. Technique of collecting data of this research are descriptive verikatif technique and deductive mindset. From the result of the research, it is concluded that kafa'ah match and criteria in LDII's members are more inclined to fellow members or groups. According to Islamic law, it does't matter to marry such a model as long as it aims to benefit and rejects the danger, because the main purpose of the Islamic law is promoting benefit for the people. In addition, during the process of matchmaking, it doesn't against the syari'ah, then it can be done. Nevertheless, it is expected that LDII's members in Medaeng, Waru, Sidoarjo are more open in understanding kafa'ah, because what is meant by kafa'ah in Islam is not limited to certain group of the people.
\end{abstract}

Keywords: Matching process, kafa'ah criteria, and LDII

Abstrak: Artikel ini adalah hasil penelitian lapangan mengenai proses perjodohan dan kriteria Kafa'ah dalam perkawinan anggota LDII di Desa Medaeng Kecamatan Waru Kabupaten Sidoarjo menggunakan perspektif hukum Islam. Penelitian ini bertujuan untuk menjawab pertanyaan tentang bagaimana proses perjodohan dalam sistem perkawinan anggota LDII di Desa Medaeng Kecamatan Waru Kabupaten Sidoarjo dan bagaimana penerapan konsep Kafa'ah dalam perkawinan anggota LDII di Desa Medaeng Kecamatan Waru Kabupaten Sidoarjo serta bagaimana analisa maslahah terhadap proses perjodohan dan konsep Kafa'ah dalam perkawinan anggota LDII di Desa Medaeng Kecamatan Waru Kabupaten Sidoarjo. Data penelitian ini diperoleh dari pengurus LDII Desa Medaeng Kecamatan Waru Kabupaten Sidoarjo yang menjadi objek penelitian. Teknik pengumpulan data penelitian ini menggunakan teknik deskriptif verikatif dengan pola pikir deduktif. Dari hasil penelitian disimpulkan, bahwa perjodohan dan kriteria Kafa'ah dalam anggota LDII yang lebih 
Sarifuddin Zuhry: Proses Perjodohan dan Kriteria Kafa'ah...

condong pada sesama anggota atau golongan. Menurut hukum Islam, boleh saja melakukan perkawinan model seperti itu selama bertujuan untuk kemaslahatan dan menolak kemadharatan, karena tujuan dari agama Islam ialah kemaslahatan umat. Selain itu, selama proses perjodohan itu tidak bertentangan dengan syariat agama, maka boleh untuk dilakukan. Meskipun demikian, diharapkan agar anggota LDII Medaeng lebih terbuka dalam memahami Kafa'ah, karena yang dimaksud kafa'ah oleh Islam ialah dalam hal agama Islam secara keseluruhan, tidak sebatas golongan tertentu.

Kata Kunci: Proses perjodohan, kriteria kafa'ah, dan LDII

\section{Pendahuluan}

Perkawinan adalah pertalian yang sah antara laki-laki dan seorang perempuan yang hidup bersama, yang tujuannya membentuk keluarga dan melanjutkan keturunan, mencegah perzinaan dan menjaga ketentraman jiwa atau batin.

Firman Allah SWT:

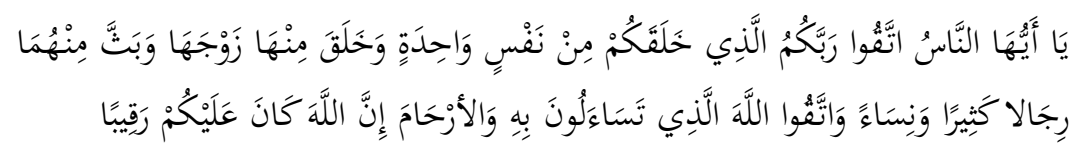

Artinya:

"Hai sekalian manusia, bertakwalah kepada Tuban-mu yang telah menciptakan kamu dari diri yang satu, dan dari padanya Allah menciptakan istrinya; dan dari pada keduanya Allah memperkembang biakkan laki-laki dan perempuan yang banyak. Dan bertakwalah kepada Allab yang dengan (mempergunakan) nama-Nya kamu saling meminta satu sama lain, dan (peliharalah) bubungan silaturahmi. Sesunggubnya Allab selalu menjaga dan mengawasikamu."(An-Nisa': 01)

Nikah itu merupakan perjanjian perikatan antara seorang lakilaki dan wanita. Perjanjian di sini bukan sembarang perjanjian, melainkan perjanjian suci untuk membentuk keluarga antara seorang laki-laki dan seorang wanita. ${ }^{2}$ Landasan perkawinan dengan nilainilai roh keislaman, yakni sakinah, mawaddah, dan rahmah dirumuskan dalam firman Allah dalam Surat Ar-Rum ayat 21 berbunyi:

1 Yayasan Penyelenggara Penerjemah Al-Quran, Al-Quran dan Terjemahnya, (Bandung: Sinar Baru Al Gresindo, 2011), 148.

2 Abd Shomad, Hukum Islam Penormaan Prinsip Syariah Dalam Hukum Indonesia (Jakarta: Kencana Prenada Media Grup, cet.2 2012), 261-262. 


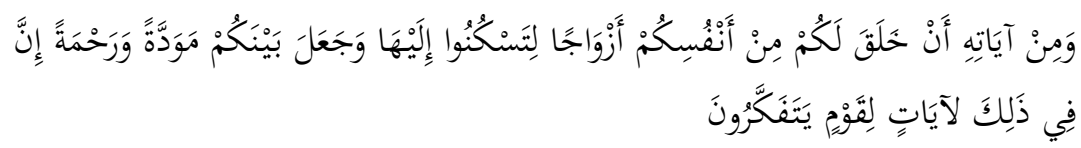

Artinya:

"Dan diantara tanda-tanda kekuasaannya ialah dia menciptakan untukmu istri-istri dari jenismu sendiri, supaya kamu cenderung dan merasa tenteram kepadanya, dan dijadikannya diantara kamu rasa kasib dan sayang. Sesunggubnya yang demikian itu berarti benar terdapat tanda-tanda bagi kaum yang berfikir. (Ar-Rum-21)".'

Dalam Undang-undang perkawinan Nomor. 01 Tahun 1974 pasal 1 disebutkan: Perkawinan adalah ikatan labir batin antara seorang pria dan seorang wanita sebagai suami istri dengan tujuan membentuk keluarga atau rumah tangga yang bahagia dan kekal berdasarkan Ketuhanan Yang Maha Esa.

Berbagai macam pendapat yang sudah dijelaskan mengenai arti pernikahan memberikan kesimpulan, bahwa pernikahan itu merupakan perjanjian yang mengikat antara seorang laki-laki dengan seorang perempuan untuk menjalani kehidupan bersama dalam berumah tangga sehingga dapat meneruskan keturunannya serta menjalankan ibadah sesuai dengan ajaran Nabi Muhammad saw. Adapun tujuan dari pada perkawinan itu adalah untuk mewujudkan kehidupan rumah tangga yang sakinah, mawaddah, dan rahmah sesuai dengan pasal 3 Kompilasi Hukum Islam. ${ }^{4}$

Dalam pandangan Islam pernikahan itu bukanlah hanya urusan perdata saja, bukan pula sekedar urusan keluarga dan masalah budaya, tetapi menyangkut keyakinan dan peristiwa agama. Oleh karena itu, pernikahan dilakukan untuk mentaati perintah Allah dan meneladani sunnah Rasulullah, dilaksanakan sesuai dengan petunjuk Allah dan petunjuk Rasullullah saw. serta mentaati prosedur yang diatur dalam peraturan negara. Di samping itu, pernikahan bukan hanya untuk mendapatkan ketenangan hidup sesaat, tetapi untuk hidup selamanya. Oleh karena itu seseorang harus memilih pasangannya secara hati-hati dan dilihat dari berbagai segi.

${ }^{3}$ Yayasan Penyelenggara Penerjemah Al-Quran...,839

${ }^{4}$ Ibid., 324. 
Ada beberapa motivasi yang mendorong seorang laki-laki memilih seorang perempuan untuk menjadi pasangan hidupnya dan demikian pula dengan seorang perempuan ketika memilih laki-laki menjadi pasangan. Hal yang pokok diantaranya adalah karena kecantikan seorang wanita atau kegagahan seorang pria atau kesuburan keduanya dalam menghasilkan anak keturunan, karena kekayaanya, kebangsawanannya, dan karena agamanya. ${ }^{5}$

Sebelum terjadinya pernikahan terdapat sebuah pertimbangan yang dalam istilah fiqih, "sejodoh" disebut dengan "Kafa'ab" artinya adalah sama, serupa, seimbang, serasi. Menurut H Abd. Rahman Ghazali, Kafa'ah atau kufu', menurut bahasa, artinya setaraf, seimbang atau keserasian/kesesuaian, serupa, sederajat atau sebanding. Sesuai dengan hadist dari Ibnu Majah yaitu:

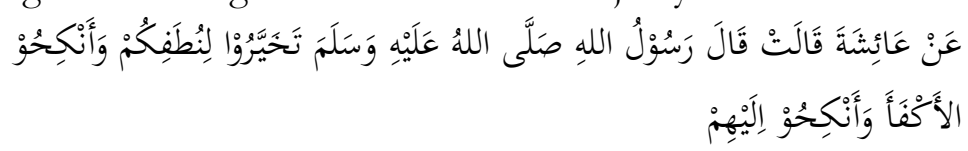

Artinya:

Dari Aisyah, ia berkata, "Rasulullah SAW bersabda, 'Pilihlah baik-baik (tempat) untuk sperma kalian, menikahlah kalian dengan yang sekufu" dan nikahkanlah (anak-anak perempuan kalian) kepada mereka (yang sekufu)'. ${ }^{6}$

Yang dimaksud dengan Kafa'ah atau kufu dalam perkawinan, menurut istilah hukum Islam, yaitu keseimbangan dan keserasian antara calon istri dan suami sehingga masing-masing calon tidak merasa berat untuk melaksanakan perkawinan. Jadi, tekanan Kafa'ah adalah keseimbangan, keharmonisan dan keserasian terutama dalam hal agama, yaitu ahlak dan ibadah.

Prof. Amir Syarifuddin dalam bukunya Hukum Perkawinan di Indonesia menyampaikan:

"Jumhur ulama termasuk Malikiyah, Syafi'iyah dan Ablura'yi (Hanafiyah) dan satu riwayat Imam Ahmad berpendapat bahwa

${ }^{5}$ Amir Syarifuddin, Hukum Perkawinan Islam di Indonesia (Jakarta: Kencana, 2011), 48.

${ }^{6}$ Abi Abdillah Muhammad bi Yazid al-Qaswaini, Sunan Ibnu Majah, hadis nomor 1968 (Beirut: Dar al-Fikr, 1424 H), 633

7 M.A. Tihami, Fikih Munakahat: Kajian Fikih Lengkap, Jakarta: Raja GrafindoPersada, 2010), 56. 
Kafa'ab itu tidak termasuk syarat dalam pernikahan dalam arti Kafa'ah itu hanya semata keutamaan dan sah pernikahan antara orang yang tidak sekufu

Alasan yang mereka gunakan ialah firman Allah surat $A$ Hujrat. 13

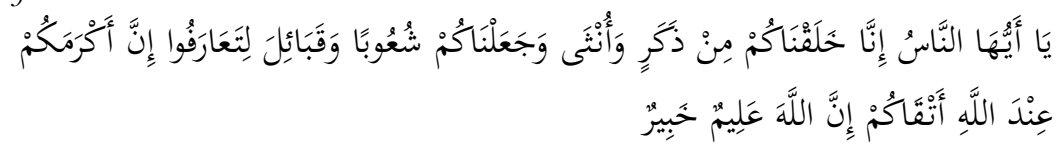

Artinya:

"Hai manusia, sesunggubnya Kami menciptakan kamu dari seorang laki-laki dan seorang perempuan dan menjadikan kamu berbangsa-bangsa dan bersuku-suku supaya kamu saling kenal mengenal. Sesunggubnya orang yang paling mulia di antara kamu di sisi Allab ialah orang yang paling bertakwa di antarakamu. Sesunggubnya Allab Maha Mengetahui lagi Maha Mengenal".

Ukuran kafa'ah yang perlu diperhatikan dan menjadi ukuran adalah sikap hidup yang lurus dan sopan, bukan karena keturunan, pekerjaan, kekayaan dan sebagainya. Seorang lelaki yang sholeh walaupun dari keturunan rendah berhak menikah dengan perempuan yang berderajat tinggi. Laki-laki yang memiliki kebesaran apapun berhak menikah dengan perempuan yang memiliki derajat dan kemasyhuran yang tinggi. ${ }^{9}$

Begitu pula laki-laki yang fakir sekalipun, ia berhak dan boleh menikah dengan perempuan yang kaya raya, asalkan laki-laki muslim dan dapat menjauhkan diri dari meminta-minta serta tidak seorang pun dari pihak walinya menghalangi atau menuntut pembatalan. Selain itu, ada kerelaan dari walinya yang mengakadkan dari pihak perempuannya. Akan tetapi jika laki-lakinya bukan dari golongan yang berbudi luhur dan jujur berarti tidak sekufu dengan perempuan yang shalihah. Bagi perempuan shalihah jika dikawinkan oleh bapaknya dengan lelaki fasik kalau perempuannya masih gadis dan dipaksa oleh orang tuanya, maka ia boleh menuntut pembatalan. ${ }^{10}$

${ }^{8}$ Yayasan Penyelenggara Penerjemah Al-Quran...,1092.

9 Abdulrahman Ghozali, Fiqih Munakahat: Kafa'ab dalam Perkawinan (Jakarta: Kencana, 2010), 96-97.

${ }^{10}$ Ibid. 
Kafa'ab dimaksudkan agar dalam membangun rumah tangga ada komunikasi yang baik dan seimbang antara suami istri sehingga akan memudahkan terwujudnya rumah tangga yang bahagia dan harmonis. ${ }^{11}$

Indonesia bukan Negara Islam akan tetapi sangat dikenal sebagai negara yang kental dengan keislamnya, sampai-sampai di Indonesia sendiri terdapat berbagai macam aliran-aliran organisasi keislaman diantaranya LDII. Lembaga Dakwah Islam Indonesia (LDII) ini adalah sebuah aliran besar di Indonesia, yang selama ini sudah sering berganti nama karena sering dilarang oleh pemerintah Indonesia. Lembaga ini didirikan oleh Mendiang Nur Hasan Ubaidah Lubis (luar biasa), pada awalnya bernama Darul Hadist, pada tahun $1995 .^{12}$

Dalam kehidupan sehari-hari LDII sangat tertutup dari masyarakat sekitar khususnya dengan ormas-ormas Islam lainnya, sehingga sampai saat ini anggota LDII masih menjadi sorotan dan terus dipantau keberadaannya oleh masyarakat sekitar. Bahkan dalam adat atau kebudayaannya pun banyak masyarakat tidak mengetahui kegiatan yang dilakukan anggota LDII seperti khususnya hal perkawinan.

Selanjutnya berdasarkan wawancara dengan anggota LDII, penulis mendapatkan keterangan bahwa dalam perkawinan anggotanya lebih ditekankan kepada sesama anggota LDII, mereka mengatakan bahwa lebih baik melaksanakan perkawinan dengan sesama anggota dengan tujuan agar terjaga aqidahnya. Hal tersebut juga didukung dengan adanya tim khusus yang menangani masalah perkawinan yang disebut dengan TIM Perkawinan. Mereka tidak menolak semisal terjadi perkawinan anggota LDII dengan anggota golongan lain, akan tetapi mereka yang dari golongan lain tersebut harus tetap belajar aqidah yang ada dalam LDII. ${ }^{13}$

Dari uraian di atas, penulis kemudian menarik sebuah kesimpulan yang mana golongan anggota LDII ini sangat memperhatikan masalah perkawinan khususnya dalam hal dengan

${ }^{11}$ Moh Saifulloh al Aziz, Fiqih Islam lengkap (Surabaya: Terbit Terang, 2005), 479.

${ }^{12}$ Hartono Ahmad Jaiz, Aliran dan Paham Sesat di Indonesia (Jakarta Timur: Pustaka Al-Kautsar, 2002), 73.

${ }^{13}$ Hasan, Wawancara, Medaeng Waru Sioarjo, 13 September 2017. 
siapa mereka harus menikah, dan ketika dihubungkan dengan hukum Islam, hal ini dapat dinamakan Kafa'ah. Masyarakat anggota LDII menganggap bahwa perkawinan yang sesuai degan konsep Kafa'ah ialah yang mana pada intinya perkawinan tersebut dilaksanakan dengan sesama anggota LDII.

Berangkat dari permasalahan di atas, penulis berkeinginan untuk melakukan penelitian dan membahasnya dalam sebuah skripsi dengan judul "Analisis Hukum Islam Terhadap Proses Perjodohan dan Kriteria Kafa'ah dalam Perkawinan Anggota Ldii (Studi Kasus di Desa Medaeng Kecamatan Waru Kabupaten Sidoarjo)”.

Penelitian tentang kafaah sudah pernah dilakukan, misalnya karya Rohmat Hidayatulloh 2016 yang berjudul Tinjanan Hukum Islam Terbadap Tradisi Pernikahan Dengan Kesetaraan Keturunan (Studi Kasus Pernikahan dikeluarga Para Mas sidosermo Kecamatan Wonocolo Kota Surabaya dan Brebek Kecamatan Waru Kabupaten Sidoarjo. Yang pada intinya menjelaskan mengenai kosep kafa'ab secara nasab atau keturunan, yang mana para mas harus menikah dengan sesama keturunan para mas karena mereka beranggapan masih ada hubungan keturunan dengan Rosullullah dari garis sayid Ali akhbar Basyaiban dan Sayid Muhammad Bagir Basyaiban. ${ }^{14}$ Ri'atul Maulani 2015 yang berjudul Tinjauan Hukum Islam Terbadap Perkawinan Jemaat Abmadiyah di Bubutan Surabaya. Yang pada intinya jemaat Ahmadiyah dalam pelaksanaan perkawinannya mempunyai adat perkawinan yang berbeda dengan ormas-ormas Islam lainya, dimana dalam hal menikah, Ahmadiyah lebih condong untuk menganut sistem Arab seperti kesultanan. Maksudnya di sini adalah demi menjaga nama organisasi Ahmadiyah, maka mereka menganut adanya norma yang mengatur perempuan Ahmadiyah di larang menikah dengan laki-laki Non Ahmadiyah. Akan tetapi, laki-laki Ahmadiyah diperbolehkan menikah dengan perempuan Non Ahmadiyah. Karena menurut kepercayaan mereka jalur nasab yang terpenting adalah dari jalur

\footnotetext{
${ }^{14}$ Rohmat Hidayatulloh, "Tinjauan hukum islam terhadap tradisi pernikahan dengan kesetaraan keturunan (studi kasus pernikahan dikeluarga para mas Sidosermo Kecamatan Wonocolo Kota Surabaya dan Brebek Kecamatan Waru Kabupaten Sidoarjo" (Skripsi - - Universitas Islam Negeri Sunan Ampel, Surabaya, 2013)
} 
ayah. ${ }^{15}$ Indah Churrotul Aini 2004 yang berjudul Presepsi Masyarakat Islam Arab di Kelurahan Ampel Kec. Semampir tentang Konsep Kafa'ah Dalam Perkawinan. Dalam skripsi tersebut berisikan mengenai bahwa pernikahan dari keturunan Arab harus dengan Keturunan Arab dengan dasar mereka menganggap masih ada keturunan dari Rosulullah dan ingin mempertahankan nasab dari Rosul tersebut. ${ }^{16} \mathrm{Ela}$ Zumrona 2002 yang berjudul Presepsi Masyarakat Islam Desa Ampel Kec. Wuluban Kab. Jember Tentang Konsep Kafa'ah Dalam Perkawinan. Mereka beranggapan bahwa kafa'ah dalam hal harta dikarenakan harta untuk memenuhi kebutuhan sehari-hari dan dapat mempengaruhi keharmonisan dalam rumah tangga. ${ }^{17}$

\section{Teori Maslahah dalam Hukum Islam}

1. Pengertian Maslahah

Maslahah berasal dari kata salaha dengan penambahan alif di awalnya yang secara arti kata berarti baik lawan dari buruk atau rusak. Maslahah adalah masdar dengan arti kata salah (حلاص) yaitu manfaat atau terlepas dari padanya kerusakan. Pengertian maslahahdalam bahasa arab adalah perbuatan-perbuatan yang mendorong kepada kebaikan manusia. ${ }^{18}$ Secara etimologi maslahah sama dengan manfaat, baik dari segi lafal maupun makna. Maslababjuga berarti manfaat atau suatu pekerjaan yang mengandung manfaat. ${ }^{19}$

Sedangkan menurut para ahli ushul berbeda-beda dalam mendefinisikan maslahah, di antaranya adalah:

a. Al Ghazali mengartikan maslahabialah

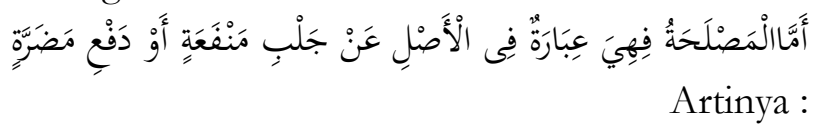

15 Ri'atul Maulani, "Tinjauan hukum islam terhadap perkawinan jemaat Ahmadiyah di Bubutan Surabaya” (Skripsi - - UIN Sunan Ampel, Surabaya, 2015) ${ }^{16}$ Indah Churrotul Aini, "Presepsi masyarakat islam Arab di Kelurahan Ampel Kec. Semampir tentang konsep kafa'ah dalam perkawinan”(Skripsi - - UIN Sunan Ampel, Surabaya, 2004)

17 Ela Zumrona, "Presepsi masyarakat islam Desa Ampel Kec. Wuluhan Kab. Jember tentang konsep kafa'ah dalam perkawinan” (Skripsi - - UIN Sunan Ampel, Surabaya, 2002)

18 Amir Syarifuddin, Ushul Fiqh 2, (Jakarta: Kencana, 2014), 367.

19 Nasrun Haroen, Usul Figh I, (Jakarta: Logos, 1996), 113. 
"Pada dasarnya maslahabadalah meraih kemanfaatan dan menolak kemadharatan". ${ }^{20}$

b. Sedangkan menurut Al Razly ialah:

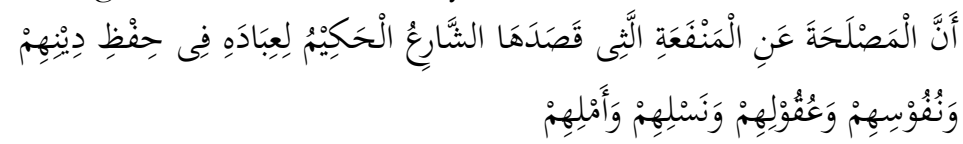

Artinya :

"Maslababadalah bentuk perbuatan yang bermanfaat yang telah diperintahkan oleh syari' (Allah) kepada hambaNya untuk memelihara agama, jiwa, akal, keturunan, dan harta benda mereka". ${ }^{21}$

c. Abdul Wahab Khallaf adalah:

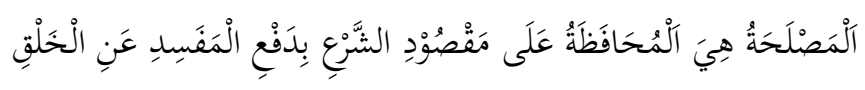

Artinya:

"Maslahah yaitu di mana syari' tidak mensyariatkan hukum untuk mewujudkan maslahah itu, juga tidak terdapat dalil yang menunjukkan atas pegakuannya atau pembatalannya". 22

Dalam kaitan dengan ini, Imam al-Syathibi, mengatakan bahwa kemaslahatan tersebut tidak dibedakan antara kemaslahatan dunia maupun kemaslahatan akhirat, karena kedua kemaslahatan tersebut apabila bertujuan untuk memelihara kelima tujuan shara' d iatas tersebut kedalam konsep maslahat. Dengan demikian menurut al-Shatibi kemaslahatan dunia yang dicapai seorang hamba Allah harus bertujuan untuk kemaslahatan di akhirat, karena kedua bentuk kemaslahatan ini selama bertujuan memelihara alKulliyat al-Khams, termasuk dalam ruang lingkup maslahah. ${ }^{23}$

20 Abd. Rahman Dahlan, Ushul Fiqh, (Jakarta: Amzah, 2011), 306

${ }^{21}$ M. Ma'shum Zein, Menguasai Ilmu Ushul Fiqh, (Yogyakarta, Pustaka Pesantren, 2013), 161.

22 Abdul Wahhab Khallaf, Kaidah-Kaidah Hukum Islam, Jakarta: Raja Grafindo Persada, cet-8 2002), 123.

${ }^{23}$ Nasrun Haroen, Usul Fiqh I, (Jakarta: Logos, 1996), 115. 
Oleh karenanya, dapat disimpulkan bahwa maslahah adalah tujuan dari syari'at Islam yaitu memelihara agama, memelihara jiwa, memelihara akal, memelihara keturunan, dan memelihara harta.

2. Macam-macam Maslahah

Para ahli ushul bersepakat untuk mengatakan bahwa maslahahdapat dibagi menjadi beberapa bagian, baik dari sisi eksistensi maupun subtansinya:

a. Dari sisi eksistensi, maslahabterbagi menjadi tiga:

1) Maslabah Mu'tabarah

Yaitu maslahabyang keberadaannya diperhitungkan oleh syara', seperti maslababyang terkandung dalam masalah pensyariatan hukum qis\}as bagi pembunuhan sengaja, sebagai simbol pemeliharaan jiwa manusia. Bentuk maslahabini oleh sebagian ulama dimasukkan kategori qiyas, misalnya hukum keharaman semua bentuk minuman yang memabukkan dengan dianalogikan kepada khomr yang keharamannya telah ditegaskan oleh nas Al Qur'an. ${ }^{24}$

2) Maslahah Mulghah

Yaitu maslahah yang dibuang lantaran bertentangan dengan syara' atau berarti maslahah yang lemah dan bertentangan dengan maslahah yang lebih utama. Bentuk ini lazimnya bersifat kontradiktif terhadap bunyi nas, baik $\mathrm{Al}$ Qur'an maupun $\mathrm{Al}$ Hadith, seperti:

a) Maslahah yang terkandung dengan hak istri untuk menjatuhkan talak kepada suami, tetapi hal ini tidak diakui oleh syara, sebab hak menjatuhkan talak hanya dimiliki oleh suami dan ini dipertimbangkan karena pertimbangan psikologis kemanusiaan.

b) Putusan seorang raja tentang "denda kafarah" berpuasa dua bulan berturut-turut sebagai ganti dari denda memerdekakan budak bagi mereka yang melakukan hubungan seks dengan istriya pada siang hari bulan Ramadhan. Bentuk maslahah di

${ }^{24}$ M. Ma’shum Zein, Menguasai Ilmu Ushul Fiqh...,163 
sini, seorang raja dengan mudah akan akan dapat membayarnya, sehingga membuat dia berpindah pada denda berikutnya, yaitu berpuasa dua bulan berturut-turut. ${ }^{25}$

\section{3) Maslabah Mursalah}

Suatu kemaslahatan yang tidak mempunyai dasar dalil, tetapi juga tidak ada pembatalannya, jika terdapat suatu kejadian yang tidak ada ketentuan syariat dan tidak ada illat yang keluar dari syara' yang menentukan kejelasan hukum kejadian tersebut, kemudian ditemukan sesuatu yang sesuai dengan hukum syara', yakni suatu ketentuan yang berdasarkan pemeliharaan kemadharatan atau unuk menyatakan suatu manfaat, maka kejadian tersebut dinamakan maslahah mursalah. Tujuan utama maslahah mursalab adalah kemaslahatan, yakni memelihara diri dari kemadharatan dan menjaga kemanfaatan. ${ }^{26}$

b. Dari sisi Subtansinya, maslahah terbagi menjadi tiga:

1) Maslabah daruruyyah (kepentingan Primer), yaitu kemaslahatan yang berhubungan dengan kebutuhan pokok umat manusia didunia dan akhirat. Kemaslahatan ini ada lima, diantaranya:

a) Memelihara agama

b) Memelihara jiwa

c) Memelihara akal

d) Memelihara harta. ${ }^{27}$

2) Maslahab hajiyyah (kepentingan sekunder), yaitu kemaslahatan yang dibutuhkan dalam menyempurnakan kemaslahatan pokok (mendasar) sebelumnya yang berbentuk keringanan untuk mempertahankan dan memelihara kebutuhan dasar manusia. Misalnya dalam hal ibadah diberi keringanan untuk meringkas (qasr) salat dan berbuka puasa bagi

${ }^{25}$ Ibid.,163

${ }^{26}$ Rachmat Syafe'i, Ilmu Ushul Fiqih, (Bandung: Pustaka Setia, 1999), 117.

${ }^{27}$ Nasrun Haroen, Usul Figh I...,115. 
orang yang musafir. Hal ini disyariatkan oleh Allah untuk mendukung kebutuhan mendasar al-masalib alkhamsah. $^{28}$

3) Maslahah tabsiniyyah (kepentingan pelengkap), yaitu mengambil apa-apa yang sesuai dengan apa yang terbaik dari kebiasaan dan menghindari cara-cara yang tidak disenangi oleh orang baik dan bijak. Ini merupakan salah satu penopang bagi kepentingan bajizyah. ${ }^{29}$

Ketiganya membentuk satu struktur yang saling berhubungan satu dengan yang lain. Artinya, pertimbangan unsure sekunder tidak boleh membatalkan tujuan asal atau primer.

3. Kehujjahan Maslabah

Para ulama usul fiqh sepakat menyatakan bahwa al-maslahah al-mu'tabarah dapat dijadikan sebagai hujjah dalam menetapkan hukum Islam. Kemaslahatan seperti ini termasuk dalam metode qiyas. Mereka juga sepakat bahwa al-maslahah al-mulghab tidak dapat dijadikan hujjah dalam menetapkan hukum Islam, demikian juga al-maslahah al-gharibah, karena tidak ditemukan dalam praktek shara'. Adapun terhadap kehujjahan al-maslabah almursalah, pada prinsipnya jumhur ulama menerimanya sebagai salah satu alasan dalam menetapkan hukum shara', sekalipun dalam penerapan dan penempatan syaratnya, mereka berbeda pendapat. ${ }^{30}$

Tentang kehujjahan maslahah mursalah, para ahli hukum Islam berpendapat:

1. Kelompok Syafi'iyyah, Hanafiyyah, sebagian Malikiyyah (seperti Ibnu Hajib), dan kelompok Al-Dhahiri berpendapat bahwa maslahah mursalah tidak dapat dijadikan hujjah untuk ber-istimbathil bukm al-syar'iy.

2. Sebagian kelopok Malikiyyah dan Syafi'iyah berpendapat bahwa maslahah mursalah dapat dijadikan hujjah dengan syarat harus memiliki semua persyaratan yang telah ditentukan

28 Ibid., 117.

${ }^{29}$ Abd. Rahman Dahlan, Ushul Figh...,165.

${ }^{30}$ Nasrun Haroen, Usul Fiqh I...,120. 
oleh para ahli hukum Islam, seprti Imam Malik sendiri, dengan alasan tujuan Allah mengutus seorang Rasul adalah untuk membimbing umat kepada kemaslahatan. Karena itu, maslahah merupakan salah satu yang pada hakikatnya dikehendaki oleh syara' atau agama, sebab tujuan utama diadakannya hukum oleh Allah hanya untuk kepentingan ummat, baik dunia maupun ahirat. ${ }^{31}$

Dari kedua pandangan tersebut, Al-Qarafiy berpendapat bahwa pada dasarnya semua madhab telah berhujjah dengan teori maslahah mursalah, sebab mereka sebab mereka telah mengaplikasikan teori qiyas, bahkan mereka sudah melakukan pembedaan antara satu dengan yang lain lantaran adanya ketentuan-ketentuan hukum yang mengikat. ${ }^{32}$

\section{Konsep Kafa'ah}

\section{Pengertian Kafa'ah}

Di dalam Islam sebelum terlaksanakannya sebuah perkawinan terdapat anjuran untuk memilih calon pasangan, yang disebut dengan istilah Kafa'ah. Dalam istilah fikih, "sejodoh" disebut dengan "Kafa'ab", artinya ialah sama, serupa, seimbang, atau serasi. Menurut H. Abd. Rahman Ghazali, "Kafa'ah atau kufu', menurut bahasa, artinya setaraf, seimbang, atau keserasian/kesesuaian, serupa, sederajat, atau sebanding". ${ }^{33}$

Persoalan mengenai Kafa'ah atau keseimbangan dalam perkawinan itu tidak diatur dalam al-Qur'an maupun Sunnah Rasul. Namun demikian karena urusan Kafa'ab ini sangat penting untuk mewujudkan suatu rumah tangga yang harmonis dan tentram, sesuai dengan tujuan perkawinan itu sendiri, maka para fuqaha banyak berijtihad dalam masalah ini. ${ }^{34}$

Sayyid Sabiq mengemukakan dalam buku Fiqh Sunnahnya bahwa yang dimaksud dengan kufu' dalam hukum perkawinan Islam ialah sama, sederajat, sepadan atau sebanding Laki-laki

${ }^{31}$ M. Ma’shum Zein, Menguasai Ilmu Ushul Fiqh...,166.

32 Ibid., 167.

${ }_{33}$ M.A. Tihami, Fikih Munakahat, Kajian Fikih Lengkap...,56.

${ }^{34}$ Soemiyati, Hukum perkawinan Islam dan Undang-Undang Perkawinan, (Yogyakarta: Liberty, 2007), 85. 
sebanding dengan calon istrinya, sama dalam kedudukan, sebanding dalam tingkat sosial dan sederajat dengan akhlak serta kekayaan. ${ }^{35}$

Perihal sebanding atau sepadan ini ditujukan untuk menjaga keselamatan dan kerukunan dalam pernikahan, bukan untuk kesahannya. Artinya sah atau pernikahan tidak tergantung pada Kafa'ab ini. Pernikahan tetap sah menurut hukum walaupun tidak sekufu' antara suami istri. ${ }^{36} \mathrm{Kafa}$ 'ah dalam perkawinan tidak menjadikan sah atau tidaknya, akan tetapi Kafa'ab ialah hak bagi perempuan dan walinya untuk membatalkan suatu perkawinan. ${ }^{37}$

Para fuqaha sepakat bahwa Kafa'ab merupakan hak perempuan dan walinya. Jika seorang perempuan kawin dengan orang yang tidak setara, maka para walinya memiliki hak untuk menuntuk pembatalannya. ${ }^{38}$

Jumhur fuqaha menilai bahwa Kafa'ah dituntut oleh perempuan, bukannya laki-laki. Dengan arti, sesungguhnya Kafa'ah dianggap di pihak laki-laki bukan di pihak perempuan. Ini adalah hak untuk kepentingan perempuan, bukannya kepentingan laki-laki. Disyariatkan laki-laki harus sebanding dengan perempuan atau mendekati tingkatannya.

Sedangkan tidak disyaratkan sebanding dengan laki-laki atau mendekati tingkatannya. Bahkan sah jika perempuan lebih rendah darinya dalam berbagai perkara Kafa'ah karena seorang laki-laki tedak memandang rendah seorang istri yang tingkatannya lebih rendah darinya. Sedagkan perempuan dan sanak kerabatnya memandang rendah suami yang tingkatannya lebih rendah darinya. ${ }^{39}$

2. Dasar Hukum Kafa'ah

Kafa'ah dianjurkan oleh Islam dalam memilih calon suami/istri, tetapi tidak menentukan sah atau tidaknya perkawinan. Kafa'ah adalah hak bagi wanita atau walinya. Karena

\footnotetext{
35 Sayyid Sabiq, Figh as-Sunnah. Jilid 2...,225

36 Ibnu Mas’ud, Fiqih Madz̧hab Syafi'i. cet. 2, ( Bandung: Pustaka Setia, 2007), 261

${ }^{37}$ Abi Bakar Al Masyhuri, I'anah at Tholibin, ( Beirut : Dar Ibn 'Ashoshoh, 2005), 377.

38 Wahbah Az Zuhaili, Fiqih Islam juz 9, , (Damaskus: Darul Fikr,2007), 220.

${ }^{39}$ Ibid.,222.
} 
perkawinan yang tidak seimbang, serasi/sesuai akan menimbulkan problema berkelanjutan, dan besar kemungkinan menyebabkan terjadinya perceraian, oleh karena itu, boleh dibatalkan. $^{40}$

Dengan demikian Kafa'ah hukumnya adalah dianjurkan, seperti dalam hadits Abu Hurairah yang dijadikan dasar tentang Kafa'ah, yaitu:

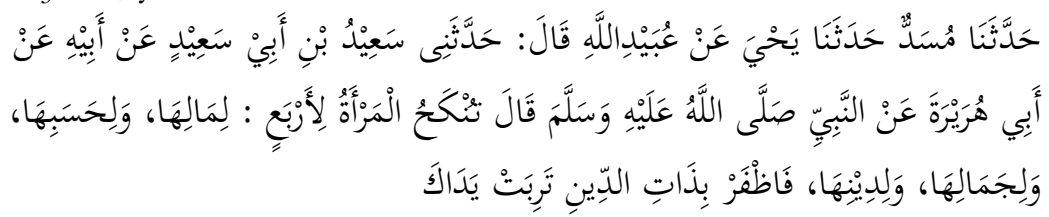

Artinya:

"Telah menceritakan kepada kami Musaddad, telah menceritakan kepada kami Yahya dari 'Ubaidillah berkata: telah mengabarkan kepadaku Sa'id bin Abu Sa'id dari ayahnya dari Abu Hurairah dari Nabi shallallabu 'alaibi wasallam beliau bersabda: "Seorang wanita dinikahi karena empat perkara; karena hartanya, keturunannya, kecantikannya, dan karena agamanya, maka pilihlah karena agamanya, niscaya kamu beruntung. (H.R. Bukhori)". ${ }^{41}$

Dari penjelasan diatas maka dapat diambil kesimpulan bahwa jika seorang laki-laki akan menikahi seorang perempuan maka ia harus memperhatikan empat perkara yaitu, hartanya, derajatnya (nasab), kecantikan dan agamanya, namun Nabi saw., sangat menekankan faktor agama untuk dijadikan pertimbangan dalam memilih pasangan.

Juga hadis Rasulullah dari Ibnu Majah yaitu:

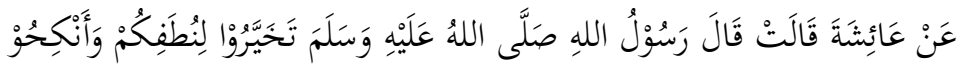

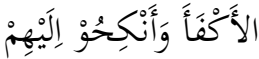

Artinya :

Dari Aisyah, ia berkata, "Rasulullah saw bersabda, 'Pilihlah baikbaik (tempat) untuk sperma kalian, menikahlah kalian dengan

40 Abdul Rahman Ghozali, Figh Munakahat...,97.

${ }^{41}$ Shohih Bukhori, Kutbus As-Sittah, (Riyadh, Darus As-Salam,2008),440. 
yang sekufu" dan nikahkanlah (anak-anak perempuan kalian) kepada mereka (yang sekufu)'. ${ }^{42}$

3. Ukuran Kafa'ah

Masalah Kafa'ah yang perlu diperhatikan dan menjadi ukuran adalah sikap hidup yang lurus dan sopan, bukan karena keturunan, pekerjaan, kekayaan, dan sebagainya. Seorang lelaki yang sholeh walaupun dari keturunan rendah berhak menikah dengan perempuan yang berderajat tinggi. Laki-laki yang memiliki kebesaran apapun berhak menikah dengan perempuan yang memiliki derajat dan kemasyhuran yang tinggi. Begitu pula laki-laki yang fakir sekalipun, ia berhak dan boleh menikah dengan perempuan yang kaya raya, asalkan laki-laki muslim dan dapat menjauhkan diri dari meminta-minta serta tidak seorang pun dari pihak walinya menghalangi atau menuntut pembatalan. ${ }^{43}$

Para imam madhab berselisih pendapat mengenai ukuran yang dijadikan tolak ukur Kafa'ah, sebagai berikut:

Menurut Hanafiyah yang menjadi dasar Kafa'ah adalah:

a. Nasab, yaitu keturunan atau kebangsaan.

b. Islam, yaitu dalam silsilah kerabatnya banyak yang beragama islam.

c. Merdeka.

d. Hirfah, profesi dalam kehidupan.

e. Diyanah, tingkat kualitas keberagamaan dalam Islam.

f. Kekayaan.

Menurut ulama Syafi'iyah yang menjadi kriteria Kafa'ah itu adalah:

a. Agama.

b. Nasab (keturunan),

c. Merdeka (bukan budak),

d. Pencaharian (kekayaan), dan

e. Bebas dari cacat. ${ }^{44}$

42 Abi Abdillah Muhammad bi Yazid al-Qaswaini, Sunan Ibnu Ma>jah, hadis nomor 1968 (Beirut: Da>r al-Fikr, 1424 H), 633

43 Abdul Rahman Ghozali...,98.

${ }^{44}$ Soemiyati, Hukum Perkawinan Islam dan Undang-Undang Perkawinan...,85. 
Menurut ulama Malikiyah yang menjadi kriteria Kafa'ah hanyalah diyanah atau kualitas keberagamaan dan bebas dari cacat fisik.

Menurut ulama Hanabilah yang menjadi kriteria Kafa'ab itu adalah:
a. Kualitas keberagamaan
b. Usaha atau profesi
c. Kekayaan
d. Kemerdekaan diri, dan
e. Kebangsaan. ${ }^{45}$

Adapun macam-macam Kafa'ah menurut para ulama dapat digolongkan menjadi beberapa macam:

a. Agama, kesucian, atau keteladanan.

Yang dimaksud adalah kebenaran dan kelurusan terhadap hukum-hukum agama. Orang yang bermaksiat dan fasik tidak sebanding dengan perempuan yang suci, atupun perempuan yang shalihah yang merupakan anak orang shalih atau perempuan ynag lurus, yang dia keluarganya memiliki jiwa agamis dan ahlak yang terpuji. Berdasarkan pada firman Allah:

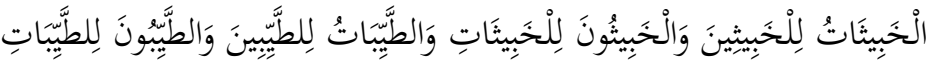

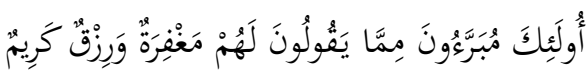

Artinya:

"Wanita-wanita yang keji adalah untuk laki-laki yang keji, dan laki-laki yang keji adalah buat wanita-wanita yang keji (pula), dan wanita-wanita yang baik adalah untuk laki-laki yang baik dan lakilaki yang baik adalah untuk wanita-wanita yang baik (pula). Mereka (yang ditudub) itu bersih dari apa yang ditudubkan oleh mereka (yang menuduh itu). Bagi merek a ampunan dan rezeki yang mulia (surga)" (An-Nur:26). ${ }^{46}$

Oleh karena itu, orang laki-laki yang fasik tidak sebanding dengan orang perempuan yang sholehah yang merupakan anak perempuan orang sholeh. Dia sebanding

45 Amir Syarifuddin, Hukum Perkawinan Islam di Indonesia...,142.

${ }^{46}$ Yayasan Penyelenggara penterjemah Al-Quran..., 835. 
dengan perempuan yang fasik yang merupakan anak perempuan orang yang fasik. ${ }^{47}$

b. Islam

Sekufu' dalam Islam pada umumnya dikenal dengan melihat pada suami, ayah, kakek, dan lainnya (jalur nasabnya). Adapun pada orang Arab tidak menganggap demikian Karen aorang Arab menganggap Kafa'ab Islam bukan dari nasabnya ke atas melainkan dari ahir nasabnya (keislaman dirinya).

Sedangkan golongan selain orang Arab menganggap sepadan dikarenakan nasabnya, maka baru mereka memilih keislamannya. Mereka menganggap laki-laki yang ayahnya islam tidak sepadan dengan perempuan yang tidak memiliki ayah Islam. Seperti halnya demikian, laki-laki yang dirinya Islam tidak sebanding dengan perempuan yang ayahnya Islam. Laki-laki yang memiliki seorang ayah Islam tidak sebanding dengan perempuan yang memiliki dua orang ayah Islam, akan tetapi dapat dikatakan sebanding ketika laki-laki tersebut memiliki dua ayah Islam.

Dari keterangan diatas dapat disimpulkan Islam yang dikenal dalam oleh orang Arab ialah Islamnya dirinya sendiri bukan dari ayah ataupun kakek, sedangkan dari selain orang Arab Islam adalah dari suami, ayah, kakek naik ke atas. ${ }^{48}$

c. Kemerdekaan

Budak laki-laki tidak sebanding dengan perempuan yang merdeka, dan tidak sebanding juga laki-laki yang dimerdekakan (bekas budak) dengan perempuan yang merdeka dari asalnya. ${ }^{49}$

Sufyan al-Tsauri dan Imam Ahmad berpendapat bahwa wanita Arab tidak boleh menikah dengan hamba sahaya laki-laki. ${ }^{50}$ Faktor kemerdekaan juga tidak diperselisihkan lagi dikalangan madhab Maliki bahwa ia termasuk dalam lingkup Kafa'ah. Hal ini didasarkan adanya

${ }^{47}$ Wahbah az Zuhaili, Fiqib Islam 9...,223-224.

${ }^{48}$ Muhammad Qadri Basa, Ahwal as Syahshiyah, (Bairut: Dar Salam, 2009), 179.

${ }^{49}$ Sayyid Sabiq, Fiqib Sunnah juz 2..., 250.

50 Abdul Rahman Ghozali, Figh Munakahat ...,57-58. 
hadis sahih yang memberikan hak khiyar kepada hamba sahaya perempuan yang telah dimerdekakan (yakni hak memilih untuk meneruskan atau tidak perkawinannya dengan suaminya yang masih berstatus hamba sahaya).

d. Nasab

Tidaklah dikatakan sekufu' pernikahan orang bangsawan Arab dan rakyat jelata atau sebaliknya. Begitu juga seorang yang berasal dari keturunan zina tidak sepadan menikah dengan orang yang berasal dari keturunan dengan jalan nikah yang sah. ${ }^{51}$

Dalam menempatkan nasab atau kebangsaan sebagai kriteria Kafa'ah ulama berbeda pendapat. Jumhur ulama menetapkan nasab atau kebangsaan sebagai kriteria dalam Kafa'ah. Dalam pandangan ini orang yang bukan orang Arab tidak setara dengan orang Arab. Ketinggian orang Arab itu menurut mereka karena Nabi sendiri adalah orang Arab. Bahkan diantara orang Arab, kabilah Qureisy lebih utama dibandingkan dengan bukan Qureisy. Alasannya seperti tadi yaitu Nabi sendiri adalah dari kabilah Qureisy. ${ }^{52}$

e. Harta

Yang dimaksud adalah kemampuan untuk memberikan mahar dan nafkah untuk istri, bukan kaya dan kekayaan. Oleh sebab itu, orang yang miskin tidak sebanding dengan perempuan yang kaya.

Sebagian madzab Hanafi menetapkan kemampuan untuk memberikan nafkah selama satu bulan. Sebagian ulama lainnya berpendapat cukup sekedar mencari rizeki untuknya. Madzab Hanafi dan Hambali mensyaratkan kemampuan sebagai unsur Kafa'ah. Karena Nabi bersabda dalam hadis riwayat Fatimah binti Qais yang telah disebutkan,

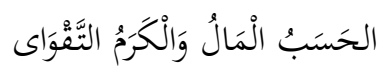

Artinya :

${ }^{51}$ Ibnu Mas’ud, Fiqih Madzhab Syafi'i. cet. 2..., 264.

52 Amir Syarifuddin, Hukum Perkawinan Islam di Indonesia..., 143. 
"Kedudukan seseorang itu menurut hartanya dan kemuliaan itu tergantung ketaqwaaanya". ${ }^{53}$

Sedangkan madhab Syafi'i dan madhab Maliki berpendapat, kemakmuran tidak masuk dalam sifat Kafa'ab karena harta merupakan sesuatu yang dapat hilang. Dan tidak menjadi kebanggan bagi orang yang memiliki nama baik dan penglihatan yang jauh. ${ }^{54}$

f. Pekerjaan atau Profesi

Yang dimaksud adalah pekerjaan yang dilakukan oleh seseorang untuk mendapatkan rizekinya dan penghidupannya, termasuk diantaranya adalah pekerjaan dipemerintah. ${ }^{55}$

Seorang perempuan dan suatu keluarga yang pekerjaannya terhormat tidak sekufu' dengan laki-laki yang pekerjaanya kasar. Tetapi kalau pekerjaannya itu hampir bersamaan tingkatnya antara satu dengan yang lain maka tidaklah dianggap ada perbedaan. Untuk mengetahui pekerjaan yang terhormat atau kasar, dapat diukur dengan kebiasaan masyarakat setempat. Sebab adakalanya pekerjaan terhormat pada suatu tempat, kemungkinan satu ketika dipandang tidak terhormat disuatu tempat dan masa yang lain. ${ }^{56}$

g. Terbebas dari Cacat

Cacat atau aib di sini ialah yang membolehkan memilih dalam pernikahan maka tidaklah sekufu' pernikahan yang berpenyakit kusta atau balak dengan orang yang sehat badannya. Orang yang berpenyakit TBC, syphilis dan lainlain tidaklah sekufu' menikah dengan orang yang berbadan sehat. ${ }^{57}$

Dan para fuqaha yang berpendapat adanya penolakan nikah karena adanya cacat, mereka akan menganggap

${ }^{53}$ Ibn Qudamah, Al-Mugni, (Beirut: Dar Al Kutub Al Ilmiyah), 377

${ }^{54}$ Wahbah az-Zuhaili, Fikib Islam 9...,228.

55 Ibid.,228.

56 Sayyid Sabiq, Fikih Sunnah...,45.

${ }^{57}$ Ibnu Mas'ud, Fiqib Madz̧ab Syafi'i. cet. 2..., 265. 
keselamatan dari cacat merupakan termasuk dalam lingkup Kafa'ah. ${ }^{58}$

\section{Kedudukan Kafa'ah Dalam Perkawinan}

Para fuqaha empat madhab dalam pendapat rajah madhab Hambali dan menurut pendapat yang mu'tamad dalam mazhab Maliki serta menurut pendapat yang paling $\mathrm{z}$ \} ahir dalam madhab Syafi'i, bahwa Kafa'ah adalah syarat lazim dalam perkawinan bukan syarat sahnya dalam perkawinan. Jika seorang perempuan yang tidak setara maka akad tersebut sah. Para wali memiliki hak untuk merasa keberatan terhadapnya dan memiliki hak untuk dibatalkan pernikahannya. Untuk mencegah timbulnya rasa malu dari diri mereka. Kecuali jika mereka jatuhkan hak rasa keberatan maka pernikahan mereka menjadi lazim. Seandainya Kafa'ah wujud syarat sahnya pernikahan, pernikahan pasti tidak sah tanpanya, walaupun para wali telah menanggalkan hak mereka untuk merasa keberatan karena syarat untuk mensahkan tidak jatuh dengan penanggalan. ${ }^{59}$

Menurut madhab Hanafi Kafa'ah secara general termasuk syarat kelaziman. Akan tetapi yang difatwakan oleh para fuqaha mutakhirin (pelengkap) bahwa Kafa'ah adalah syarat bagi sahnya perkawinan dalam sebagian kondisi, dan syarat untuk pelaksaannya bagi beberapa kondisi, dan syarat untuk kelazimannya dalam kondisi yang lain. Sedangkan kondisi yang menjadikan Kafa'ah sebagai syarat sahnya perkawinan adalah sebagai berikut:

1. Jika seorang perempuan yang sudah akil baligh mengawinkan dirinya sendiri dengan orang yang tidak setara dengannya atau dengan tipuan yang besar, dan dia memiliki wali 'ashabah tidak merasa ridha dengan perkawinan ini sebelum terlaksananya akad, maka perkawinan ini tidak sah dari sejak asalnya, tidak juga menjadi lazim, tidak bergantung kepada keridhaan setelah baligh.

2. Jika wali selain bapak atau kakek atau keturunan anak laki-laki mengawinkan seorang tidak memiliki kemampuan atau

58 Abdul Rahman Ghozali, Fiqh Munakahat...,100.

${ }^{59}$ Wahbah az-Zuhaili, Fikib Islam 9...,218. 
kurang kemampuannya, maksudnya orang gila laki-laki atau orang gila perempuan, anak kecil laki-laki, anak kecil perempuan dengan orang yang tidak setara. Sesungguhnya perkawinan ini adalah perkawinan yang fasid karena perwalian mereka itu terikat dengan maslahat, dan tidak ada maslahat dalam mengawinkannya dengan orang yang tidak setara.

3. Jika seorang bapak atau anak laki-laki yang dikenal buruk dalam memilih, mengawinkan seorang perempuan tidak memiliki kemampuan atau kurang kemampuannya, dengan seorang laki-laki yang tidak setara, atau dengan tipuan yang besar, maka fuqaha sepakat bahwa pernikahan ini tidak sah. Begitu juga halnya jika dia dalam keadaan mabuk, maka dia kawinkan seorang perempuan dengan orang fasik atau orang jahat, atau orang miskin atau orang yang memiliki profesi rendah, karena timbulnya pilihan yang buruk serta tidak adanya maslahat dalam perkawinan ini. ${ }^{60}$

\section{Perjodohan dan Konsep Kafa'ah dalam Perkawinan Anggota LDII Desa Medaeng}

1. Proses perjodohan dalam perkawianan LDII

Perkawinan menurut LDII adalah perintah Allah SWT dan Rasulallah saw, selain itu perkawinan ialah suatu jalan yang menghindarkan manusia dari perbuatan zina. LDII menganggap mengenai tujuan perkawinan ialah untuk mencapai nilai-nilai roh keislaman yakni sakinah, mawaddah, dan rahmah yang dirumuskan dalam firman Allah dalam Surat Ar-Rum ayat 21 berbunyi:

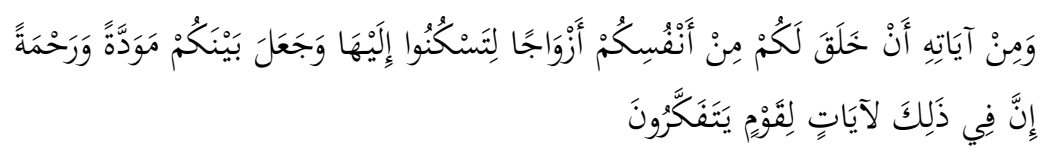

Artinya :

"Dan diantara tanda-tanda kekuasaannya ialah dia menciptakan untukmu istri-istri dari jenismu sendiri, supaya kamu cenderung dan merasa tenteram kepadanya, dan dijadikannya diantara kamu rasa kasih

${ }^{60}$ Ibid.,219. 
dan sayang. Sesunggubnya yang demikian itu berarti benar terdapat tandatanda bagi kaum yang berfikir. (Ar-Rum-21)". ${ }^{61}$

LDII menganggap perkawinan merupakan hal yang penting yang harus diperhatikan sejak dini. Hal ini dapat dibuktikan dengan adanya persiapan yang dilakukan oleh pengurus LDII khususnya yang disebut dengan TIM pernikahan, melalui kajiankajian perkawinan pada usia pra nikah dan pasca nikah.

Dalam organisasi LDII terdapat proses tatacara perkawinan yang dilangsungkan. Dimana tatacara perkawinan, yaitu:

a. Penyeleksian anggota usia kawin

b. Proses pencarian jodoh

c. Pelaksanaan perkawinan

d. Disarankan perkawinan antara anggota LDII sesama anggota LDII. $^{62}$

Dari urutan tatacara di atas diuraikan sebagai berikut: Pertama, tim pernikahan mendata seluruh anggota LDII yang telah memasuki usia kawin dengan cara mendata nama, orang tua, alamat, pekerjaan, dan ciri-ciri fisik. Kemudian seluruh data tersebut disebar keseluruh Indonesia guna memasuki tahap yang selanjutnya.

Kedua, selanjutnya ialah memasuki proses pencarian jodoh yang dilakukan oleh setiap anggota yang menghendaki kawin, dengan cara memilih pada data yang telah disiapkan oleh tim pernikahan. Disini anggota memilih calon yang cocok dengannya, dan ketika telah menemukan yang sesuai dengan yang diinginkan tim pernikahan akan mengabari kepada pihak yang dimaksud serta mempersiapkan proses untuk ta'ruf. Setelah proses ta'aruf selesai dan keduanya merasa cocok kemudian dari tim pernikahan menyiapkan surat lamaran dan penentuan hari pernikahan yang telah ditanda tangani oleh pihak laki-laki, tim pernikahan, dan saksi.

Ketiga, pelaksanaan perkawinan dilaksanakan seperti halnya pada umumnya perkawinan. Anggota LDII juga melaksanakan perkawinan di KUA, akan tetapi ada sebagian dari anggota LDII

${ }^{61}$ Yayasan Penyelenggara Penerjemah Al-Quran....,839

${ }^{62}$ Hasan, Wawancara, Medaeng Waru Sidoarjo, 13 September 2017

The Indonesian Journal of Islamic Family Law Volume 08, Nomor 01, Juni 2018 
yang melakukan perkawinan sirri terlebih dahulu sebelum melakukan perkawinannya di KUA.

Keempat, pernikahan anggota LDII hendaknya dilakukan dengan sesama anggota LDII, hal ini sangat dianjurkan bahkan mereka menganggap berhukum fardlu 'ain. Oleh karenanya anjuran ini sangat berberhungan erat dengan pendataan anggota yang siap untuk kawin, dengan tujuan mereka memilih pasanganya dari golongan LDII sendiri. ${ }^{63}$

2. Kreteria Konsep Kafa'ah dalam Perkawinan Anggota LDII Medaeng

Pernikahan merupakan ikatan lahir batin antara seorang lakilaki dan perempuan sebagai suami dan istri dengan tujuan membentuk keluarga rumah tangga yang bahagia dan kekal yang berdasarkan Ketuhanan Yang Maha Esa. ${ }^{64}$

Kafa'ah atau kufu' menurut bahasa artinya setara, seimbang, keserasian, kesesuaian, serupa, sederajat atau sebanding. Kafa'ah atau kufu' dalam perkawinan menurut hukum Islam yaitu keseimbangan atau keserasian antara calon istri dan suami sehingga masing-masing calon tidak merasa berat untuk melangsungkan perkawinan. atau laki-laki sebanding dengan calon istrinya, sama dengan kedudukan, sebanding dalam tingkat sosial dan sederajat dalam akhlak serta dalam kekayaan. Jadi, yang ditekankan dalam hal kafa'ah adalah keseimbangan, keharmonisan dan keserasian, terutama dalam hal agama, yaitu ahlak dan ibadah. ${ }^{65}$

Melihat pentingnya kesetaran dalam berlangsungnya perkawinan, alangkah baiknya jika praktek kafa'ah ini diterapkan oleh setiap orang Islam. Setiap ulama tentu memiliki pandangan berbeda mengenai konsep kafa'ah, sebagaimana yang telah dijelaskan di atas. Bahkan, beberapa organisasi Islam pun mempunyai praktek kafa'ah menurut pandangan mereka sendiri, Misalnya LDII (Lembaga Dakwah Islam Indonesia).

${ }^{63}$ Rusdi, Wawancara, Medaeng Waru Sidoarjo, 12 Maret 2018.

${ }^{64}$ Undang-Undang RI Nomor 1 Tahun 1974 Tentang Perkawinan, Pasal 1, 2.

65 Abd. Rahman Ghazaly, Fiqh Munakahat, Jakarta: Prenada Media, 2003), 96-97. 
LDII Medaeng berpendapat bahwa seseorang yang hendak melaksanakan perkawianan agar memilih pasangan yang sepadan atau setara, atau disebut dengan istilah sekufu'. Tolak ukur kafa'ah dalam perkawinan LDII Medaeng yang paling penting ialah dalam hal agamanya. Misalnya, orang sholeh harus mendapatkan orang yang sholihah. Dan untuk dicapainya suatu kafa'ah tersebut LDII Medaeng memiliki pandangan tersendiri, mereka beranggapan seorang perempuan akan dinilai setara jika dikawinkan dengan seorang laki-laki yang segolongan dengannya, yakni sama-sama anggota LDII. ${ }^{66}$ Secara sekilas, konsep kafa'ah seperti ini tentunya seakan-akan menyeleweng dari ketentuan yang telah diajarkan oleh para ulama. Dalam hal ini penulis menegaskan lagi bahwa praktek kafa'ah dalam anggota LDII adalah satu golongan.

Dalam ajaran Lembaga Dakwah Islam Indonesia tentang kafa'ah mereka menggunakan dasar hukum pada firman Allah SWT.

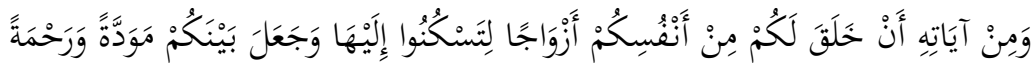

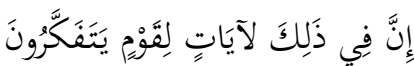

Artinya:

Dan di antara tanda-tanda kekuasaan-Nya ialah Dia menciptakan untukmu istri-istri dari jenismu sendiri, supaya kamu cenderung dan merasa tenteram kepadanya, dan dijadikan-Nya di antaramu rasa kasib dan sayang. Sesunggubnya pada yang demikian itu benar-benar terdapat tanda-tanda bagi kaum yang berpikir (Ar-Rum: 21). ${ }^{67}$

Berdasar dari ayat diatas LDII Medaeng berpendat bahwa perkawinan yang sesuai dengan konsep kafa'ah harusnya dilaksanakan sesuai dengan "jenis". LDII Medaeng menganggap bahwa yang diartikan dengan jenis ialah jenis golongan yaitu sama-sama dari LDII. Ketika suatu perkawinan yang dilakukan dengan sesama LDII menurut pandangan LDII Medaeng nantinya akan ditemukan keharmonisan dalam keluarga dan

${ }^{66}$ Rusdi, Wawancara, Medaeng Waru Sidoarjo, 12 Maret 2018.

${ }^{67}$ Yayasan Penyelenggara Penerjemah Al-Quran, et el. ..., 839. 
bahkan sampai mengurangi perceraian. ${ }^{68}$ Dan hadits Rasulullah yang diriwayatkan oleh Abu Hurairah ra.

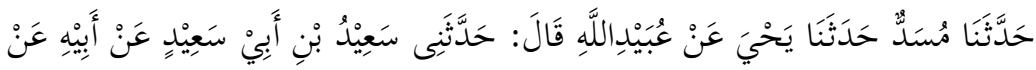

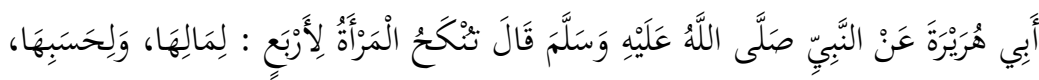

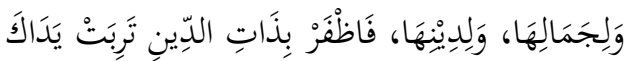

Artinya:

"Telah menceritakan kepada kami Musaddad, telah menceritakan kepada kami Yahya dari 'Ubaidillah berkata: telah mengabarkan kepadaku Sa'id bin Abu Sa'id dari ayahnya dari Abu Hurairah dari Nabi shallallahu 'alaibi wasallam beliau bersabda: "Seorang wanita dinikahi karena empat perkara; karena hartanya, keturunannya, kecantikannya, dan karena agamanya, maka pilihlah karena agamanya, niscaya kamu beruntung. (H.R. Bukhori)"'. ${ }^{69}$

Selaras dengan ayat hadits diatas maka dapat disimpulkan bahwa LDII Medaeng menganggap perkawinan dapat dikatakan kafa'ah ketika telah sesuai dengan hadits Nabi. Akan tetapi mereka selain berpegang pada hadits tersebut mereka juga memiliki pertimbang sebgai berikut:

1. Agama

LDII menganjurkan ketika hendak memilih pasangan dalam perkawinan ditekankan untuk segama, yaitu agama Islam. Dengan alasan agama merupakan pokok dari kehidupan dan agama islam merupakan agama yang haq. Hal tersebut juga bertujuan agar dapat membina keluarga yang sakinah, mawaddah, wa rahmah.

Dalam LDII Medaeng seluruh anggotanya selain dianjuran untuk memilih pasangan suami atau istri seagama. Juga, yang paling utama dalam memilih pasangan hendaknya ialah seanggota atau seajaran, dalam artian sama-sama LDII.

Mereka menganggap bahwa anjuran pernikahan yang sesama anggota LDII tersebut nantinya akan mempengaruhi suatu kehidupan berkeluarga, bahkan mereka mengungkapan

${ }^{68}$ Rusdi, Wawancara, 12 Maret 2018.

${ }^{69}$ Shohih Bukhori, Kutbus As-Sittah, (Riyadh, Darus As-Salam,2008),440. 
ketika terjadi perkawinan beda organisasi bisa mengakibatkan perceraiaan.

2. Harta

Berdasarkan hadits Rasulullah LDII Medaeng menganggap bahwa harta merupakan bagian dari kafa'ah. Akan tetapi, walaupun menganggap harta merupakan bagian kafa'ah mereka tidak semata-mata menganggap harta sebagai faktor penting dalam kafa'ah perkawinan.

Harta adalah titipan Allah SWT kepada hambanya, selagi manusia giat bekerja dan berusaha maka InsaAllah rizki akan menghampiri kita, oleh karenanya anggota LDII tidak mempermasalahkan harta, asalkan ada kesepakatan dan saling memahami kekurangan dalam masalah harta mereka.

Dalam LDII tidak mempermasalahkan mengenai harta dikarenakan ketika anggotanya melakukan perkawinan, kemudian anggota tersebut mengalami kendala dalam masalah harta. Maka, akan dibantu oleh organisasi LDII untuk menyelesaikannya, dalam hal ini akan dibantu oleh para aghniya'.

Jadi, walaupun harta itu tidak dimiliki oleh anggota yang hendak malaksankan perkawinan. akan tetapi, mereka memiliki kehendak untuk menikah dan dianggap sudah siap dalam hal agama serta mental. Maka, akan dipersilahkan untuk menikah dengan dibantu oleh para aghniya'

3. Nasab

Nasab atau keturunan dalam LDII sama halnya seperti harta, LDII adalah suatu organisasi keagamaan yang mempunyai landasan dan ketetapan sendiri untuk menjalankan syariat agama, kususnya dalam hal mencari pasangan hidup, dalam masalah nasab dan kedudukan pada sebuah golongan atau aliran. Jadi, yang dimaksud kesetaraan dalam nasab adalah persamaan sebuah golongan atau aliran.

4. Kecantikan

Kecantikan, dalam LDII menganggap bahwa kecantikan merupakan salah satu yang mempengaruhi keharmonisan dalam keluarga. Akan tetapi, suatu kecantikan yang dimiliki itu relatif bagi orang yang menjalankan suatu perkawinan. Oleh 
karena, LDII tidak mempermasalahkan hal tersebut, asalkan pasangannya cantik dalam artian hatinya dan ahlaknya. ${ }^{70}$

Jadi, dari uraian di atas dapat disimpulkan bahwa terdapat perbedaan konsep kafa'ah yang ada dalam LDII. Dalam LDII tetap menganggap hadith tentang pemilihan pasangan mengenai konsep kafa'ahyang meliputi agama, harta, nasab, kecantikan. Akan tetapi, mereka menganggap hal yang paling utama ialah dalam hal agama, dalam artian agama ialah mereka yang segolongan dengan anggota yang menginginkan untuk menikah yaitu sama-sama LDII.

\section{Proses Perjodohan dalam Perkawinan Anggota LDII Desa Medaeng Perspektif Hukum Islam}

Masyarakat LDII Desa Medaeng Kecamatan Waru Kabupaten Sidoarjo tergolong masyarakat yang memiliki tingkat keperdulian terhadap keagamaan yang cukup tinggi. Hal ini tergambarkan dengan penerapan ajaran-ajarannya sesuai dengan tuntunan $\mathrm{Al}$ Qur'an dan Al Hadith.

Mengenai persyaratan perkawinan dalam LDII Medaeng yang meliputi syarat dan rukun perkawinan mereka sama seperti halnya organisasi atau golongan yang lainnya. Hal itu mereka anggap sebagai syarat yang mutlak harus dipenuhi. Akan tetapi ada beberapa proses pelaksanaan perkawinan yang berbeda dalam LDII.

Anggota LDII Medaeng dalam perkawinan sangat selektif dalam memilih pasangan hidup. Selain memperhatikan aturanaturan fikih dalam perkawinan guna untuk dicapainya tujuan-tujuan dalam perkawinan. Anggota LDII masih mempertahankan perkawinan yang dilaksanakan dengan sesama anggota LDII. Yang mana kemudian diketahui, pada LDII Medaeng terdapat suatu Tim yang dibentuk untuk menangani masalah perkawinan, meliputi pendataan usia kawin sampai proses perkawinan yang sering disebut Tim Pernikahan.

Dari hal tersebut kemudian dapat dipastikan, munculnya suatu perjodohan dalam anggota LDII Medaeng, yang dilakukan oleh Tim Perkawinan merupakan sebagai bentuk pelestarian norma-norma serta ajaran-ajaran LDII agar selalu terjaga tanpa adanya pengaruh

${ }^{70}$ Rusdi, Wawancara, Medaeng Waru Sidoarjo, 12 Maret 2018. 
dari luar golongan lain, serta dapat menghindarkan suatu perkawinan dari hal-hal yang diinginkan.

\section{Kriteria Kafa'ah dalam Perkawinan Anggota LDII Desa Medaeng Perspektif Hukum Islam}

Dalam LDII Medaeng agamalah yang menjadikan tolak ukur dalam penerapan kafa'ah. LDII Medaeng juga perpendapat bahwa mengenai masalah agama dalam penerapan kafa'ah yang lebih tepat ialah dalam hal "segolongan", yang mana ketika perkawinan yang didasari dengan golongan maka akan dapat dicapai suatu keluarga yang harmonis.

Hal tersebut juga dipercayai oleh anggota LDII Medaeng sebagai upaya pembentukan keluarga yang sakinah, mawaddah, wa rabmah serta dapat menjaga norma-norma dan ajaran-ajaran yang terkandung dalam LDII.

Artinya, mereka berpendapat penempatan agama lebih khususnya golongan yang menjadikan landasan perjodohan dan ukuran dengan siapa harus menikah. Sehingga hal tersebut sangat sulit untuk dipisahkan, mengingat perjodohan merupakan sarana dalam perkawinan, maka untuk mendapatkan hasil yang memuaskan dalam perkawinan dibutuhkan pilihan yang berdasarkan agama/golongan.

Hal tersebut berlawanan dengan pendapat para ulama madhab yang berpendapat bahwa yang menjadi tolak ukur kafa'ab yaitu mengenai empat hal, antara lain: kecantikan, nasab, harta, serta agamanya. Dan hal tersebut bersumber dari hadith Nabi, Kemudian dalam masalah penentuan kafa'ah yang dilakukan oleh anggota LDII, dapat disimpulkan tidak ada ulama madhab yang sepakat mengenai kafa'ah harus segolongan organisasi. Para ulama madhab hanya mengungkapkan bahwa kafa'ab meliputi empat hal, dan yang lebih condong kepada penerapan kafa'ah LDII hanya sebatas kafa'ah agama. Jadi, kemudian penulis menyimpulkan mengenai konsep kafa'ab yang disetujui oleh ulama madhab ialah agama Islam secara umum, bukan kafa'ah golongan.

\section{Analisis Maslahah Terhadap Proses Perjodohan dan Kriteria Kafa'ah dalam Perkawinan Anggota LDII Desa Medaeng}


Dalam teori maslahah yang paling mendasar dan menjadi tujuan utama pada intinya ialah tercapainya kemaslahatan umat baik di dunia maupun di ahirat, menolak keadharatn dan kemafsadahan, serta mewujudkan keadilan yang hakiki. Karena pada intinya manusia hidup menginginkan hidup yang nyaman baik untuk dirinya maupun orang lain.

Sebagai suatu nilai yang menitik beratkan pada kemaslahatan bersama. Hal tersebut wajar meski pada dasarnya bertentangan dengan perkawa yang mesti. Akan tetapi, urgensi kehidupan masyarakat yang berbeda-beda merupakan alasan mendasar karena setiap masyarakat memiliki kecendrungan kebutuhan yang berbeda. Guna untuk mendapatkan tujuan dari hal tersebut. Maka, kemudian diperbolehkan dalam pelaksanaannya, dengan pengecualian selagi tidak sampai bertentangan dengan aturan syariat Islam.

Dalam perkawinan anggota LDII, mengenai pemilihan pasangan atau perjodohan mereka lebih menekankan golongan sebagai sebagai bentuk penerapan konsep kafa'ah dalam perkawinan. Karena mereka memahami untuk memperoleh kehidupan yang baik. Maka, diperlukan penerapan aturan yang memiliki tujuan untuk kehidupan yang maksimal.

Walaupaun dalam penerapan dapat dikatakan kurang tepat. Akan tetapi, ketika tujuannya untuk kemaslahatan maka, hal tersebut boleh dilakukan. Sebagaimana perjodohan dalam LDII Medaeng yang lebih mengutamakan dari anggotanya sendiri. Mereka menganggap suatu perkawinan yang dilakukan dengan sesama anggota LDII akan dapat menjaga nilai-nilai dan ajaran-ajaran yang terdapat dlam LDII, dan mereka pun berpendapat penerapan perjodohan yang demikian akan mengurangi hal-hal yang tidak diinginkan dalam sebuah perkawinan.

Namun ketika dihubungkan dengan Firman Allah SWT dalam Surat Ar-Ru@m ayat 21 dan yang merupakan dasar LDII dalam menetukan pasangan, berbunyi:

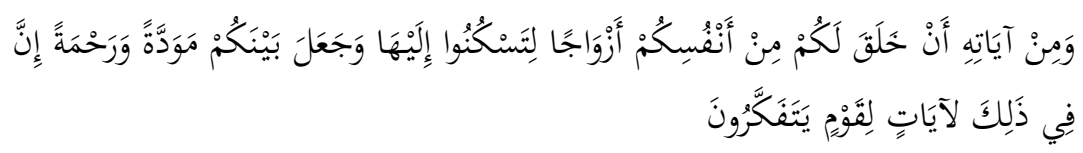

Artinya : 
"Dan diantara tanda-tanda kekuasaannya ialah dia menciptakan untukmu istri-istri dari jenismu sendiri, supaya kamu cenderung dan merasa tenteram kepadanya, dan dijadikannya diantara kamu rasa kasib dan sayang. Sesunggubnya yang demikian itu berarti benar terdapat tanda-tanda bagi kaum yang berfikir. (Ar-Rum-21)". ${ }^{71}$

Dari ayat di atas dapat disimpulkan bahwa Allah SWT menciptakan manusia dalam keadaan berpasang-pasang, kemudian Allah menjadikan para istri dari umat manusia dari sesama golongannya. Dari paparan tersebut kemudian dapat disimpulkan bahwa yang menjadikan tolak ukur dalam mencari pasangan atau istri itu berdasarkan golongan yaitu sesama manusia dan yang segolongan Islam, sehingga nanti pada ahirnya akan dicapai keluarga yang mawaddah wa rahmah.

Serta hadith Nabi saw :

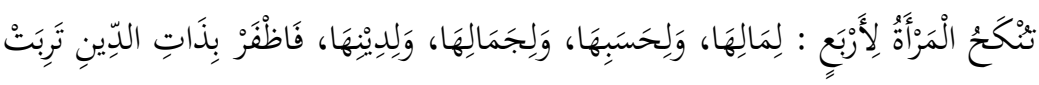

$$
\begin{aligned}
& \text { يَدَاكَ }
\end{aligned}
$$

Artinya:

"Seorang wanita dinikahi karena empat perkara; karena hartanya, keturunannya, kecantikannya, dan karena agamanya, maka pilihlah karena agamanya, niscaya kamu beruntung. (H.R. Bukhori)". ${ }^{72}$

Hadith tersebut dijelaskan bahwa dalam mencari pasangan hendaknya diperhatikan dalam masalah hartanya, keturunannya, kecantikannya, agamanya dan niscaya ketika terpenuhi kesemuanya akan dicapailah kebahagiaan dalam berkeluarga.

Dari paparan di atas mengenai proses perjodohan dalam LDII yang mengutamakan kafa'ah golongan penulis kurang setuju dengan alasan, mengenai anjuran untuk menikah dengan sesama anggota LDII, mereka mengakui mengenai adanya konsep kafa'ah sebagai aturan dalam penentuan pasangan, yang di antaranya adalah mengenai agama. Mereka masih menganggap bahwa yang disebut agama ialah yang segolongan dengan mereka (LDII). Seharusnya

${ }^{71}$ Yayasan Penyelenggara Penerjemah Al-Quran....,839

72 Shohih Bukhori, Kutbus As-Sittah, (Riyadh, Darus As-Salam,2008),440. 
ketika berbicara mengenai pemahaman agama dalam hal kafa'ah mereka harus menganggap terhadap golongan lain. Karena, tujuan utama dari konsep kafa'ab ialah agama Islam secara keseluruhan.

Walaupun mengenai konsep kafa'ah telah diatur dengan sedemikian rupa. akan tetapi, anggota LDII tetap mempertahankan pemahaman konsep kafa'ah golongan dengan fasilitas perjodohan dalam LDII. Dengan alasan konsep kafa'ah golongan, akan dapat mempertahankan ajaran-ajaran dalam LDII serta menghindarkan dari perkara yang tidak diinginkan ketika terjadi perkawinan dengan golongan lain. Maka, ketika konsep kafa'ah golongan tetap dipertahankan oleh Anggota LDII Medaeng, kemudian dianalisis dengan menggunakan teori maslahah selama tujuan perkawinan tersebut tetap bertujuan untuk melestarikan agama Islam maka diperbolehkan.

\section{Penutup}

Lembaga Dakwah Islam Indonesia dalam melaksanakan perkawinan memiliki proses yang berbeda dengan organisasi islam yang lainnya yaitu dengan adanya perjodohan yang dilakukan oleh Tim Pernikahan, yang mana tujuan utama dari Tim pernikahan ini adalah untuk menjaga norma-norma dan ajaran-ajaran dalam LDII dari pengaruh ajaran luar golongan.

Dalam LDII mereka menganggap penerapan konsep kafa'ah itu harus sesama golongan akan tetapi hal tersebut berbeda dengan pendapat para ulama madhab yang mengatakan bahwa konsep kafa'ah meliputi empat hal yaitu agama, nasab, harta dan kecantikan. Tidak ada ulama madhab yang berpendapat bahwa kafa'ah harus segolongan.

Dalam Teori maslahah yang menjadi dasar ialah tujuan menarik kemaslahatan dan menolak kemadharatan. Dalam proses perjodohan dan penerapan kafa'ah anggota LDII Medaeng, proses perjodohan tersebut merupakan sarana untuk mempertahankan ajaran-ajaran LDII serta menjaga anggotanya dari perbuatan yang dilarang oleh agama seperti halnya zina. Maka, ketika dihubungkan dengan maslahah dapat disimpulkan penarikan kemanfaatan dari perjodohan dan penerapan ialah mempertahankan ajaran agama Islam yang diyakini oleh LDII serta penolakan kemadharatan yang berupa menjaga anggotanya dari perbuatan zina. 


\section{Daftar Pustaka}

Abd Shomad, Hukum Islam Penormaan Prinsip Syariah Dalam Hukum Indonesia, Jakarta: Kencana Prenada Media Grup, cet.2 2012.

Abd. Rahman Dahlan, Ushul Fiqh, Jakarta: Amzah, 2011.

Abd. Rahman Ghazaly, Fiqh Munakahat, Jakarta: Prenada Media, 2003.

Abdul Wahhab Khallaf, Kaidah-Kaidah Hukum Islam, Jakarta: Raja Grafindo Persada, cet-8 2002.

Abdulrahman Ghozali, Fiqih Munakahat: Kafa'ah dalam Perkawinan, Jakarta: Kencana, 2010.

Abi Abdillah Muhammad bi Yazid al-Qaswaini, Sunan Ibnu Majah, hadis nomor 1968, Beirut: Dar al-Fikr, $1424 \mathrm{H}$.

Abi Abdillah Muhammad bi Yazid al-Qaswaini, Sunan Ibnu Majah, hadis nomor 1968, Beirut: Dar al-Fikr, $1424 \mathrm{H}$.

Abi Bakar Al Masyhuri, I'anah at Tholibin, Beirut : Dar Ibn 'Ashoshoh, 2005.

Amir Syarifuddin, Hukum Perkawinan Islam di Indonesia, Jakarta: Kencana, 2011.

Amir Syarifuddin, Ushul Figh 2, Jakarta: Kencana, 2014.

Ela Zumrona, "Presepsi masyarakat islam Desa Ampel Kec.

Wuluhan Kab. Jember tentang konsep kafa'ah dalam perkawinan” (Skripsi - - UIN Sunan Ampel, Surabaya, 2002)

Ghozali, Abdulrahman. Fiqih Munakahat: Kafa'ah dalam Perkawinan. Jakarta: Kencana, 2010

Hartono Ahmad Jaiz, Aliran dan Paham Sesat di Indonesia, Jakarta Timur: Pustaka Al-Kautsar, 2002.

Ibn Qudamah, Al-Mugni, Beirut: Dar Al Kutub Al Ilmiyah.

Ibnu Mas'ud, Fiqih Madzhab Syafi'i. cet. 2, Bandung: Pustaka Setia, 2007.

Indah Churrotul Aini, 'Presepsi masyarakat islam Arab di Kelurahan Ampel Kec. Semampir tentang konsep kafa'ah dalam perkawinan"(Skripsi - - UIN Sunan Ampel, Surabaya, 2004)

M. Ma'shum Zein, Menguasai Ilmu Ushul Fiqh, Yogyakarta, Pustaka Pesantren, 2013.

M.A. Tihami, Fikih Munakahat: Kajian Fikih Lengkap, Jakarta: Raja GrafindoPersada, 2010. 
Moh Saifulloh al Aziz, Fiqih Islam lengkap, Surabaya: Terbit Terang, 2005.

Muhammad Qadri Basa, Ahwal as Syahshiyah, Bairut: Dar Salam, 2009.

Nasrun Haroen, Usul Fiqh I, Jakarta: Logos, 1996.

Rachmat Syafe'i, Ilmu Ushul Fiqih, Bandung: Pustaka Setia, 1999.

Ri'atul Maulani, "Tinjauan hukum islam terhadap perkawinan jemaat Ahmadiyah di Bubutan Surabaya" (Skripsi - - UIN Sunan Ampel, Surabaya, 2015)

Rohmat Hidayatulloh, "Tinjauan hukum islam terhadap tradisi pernikahan dengan kesetaraan keturunan (studi kasus pernikahan dikeluarga para mas Sidosermo Kecamatan Wonocolo Kota Surabaya dan Brebek Kecamatan Waru Kabupaten Sidoarjo" (Skripsi - - Universitas Islam Negeri Sunan Ampel, Surabaya, 2013)

Sayyid Sabiq. Fiqh as-Sunnah jilid 7. Bandung: PT Al-Ma'arif ,1981.

Shohih Bukhori, Kutbus As-Sittah, Riyadh, Darus As-Salam, 2008. Soemiyati, Hukum perkawinan Islam dan Undang-Undang Perkawinan, .Yogyakarta: Liberty, 2007.

Wahbah Az Zuhaili, Fiqib Islam juz 9, Damaskus: Darul Fikr,2007.

Undang-Undang RI Nomor 1 Tahun 1974 Tentang Perkawinan

Yayasan Penyelenggara Penerjemah Al-Quran, Al-Quran dan Terjemahnya, Bandung: Sinar Baru Al Gresindo, 2011.

Rusdi, Wawancara, Medaeng Waru Sidoarjo, 12 Maret 2018. Hasan, Wawancara, Medaeng Waru Sidoarjo, 13 September 2017 